\title{
Response to Rev S P Mpanza's paper on the role of the church in the struggle against poverty with reference to the Reconstruction and Development Programme
}

Z J Banda

Ga-Rankuwa

\section{THE HISTORY OF COLLABORATION OF THE CHURCH AND THE GOVERNMENT ON ISSUES OF POVERTY: AN OVERVIEW OF THE PERIOD 1900 TO 1994}

\subsection{Introduction}

In South Africa the issue of poverty and its extent is not new. Since the time of our recorded past, with the coming of Whites to this most Southern part of the African continent, there have been various incidents of poverty caused by natural elements (e.g. droughts), beliefs (the Nongqause tragedy); wars (e.g. Lifaqane, Anglo-Boer War); diseases (e.g. Rinderpes); systematic deprivation by Government policies (e.g. apartheid) and other factors. Our topic 'The Church and the Reconstruction and Development Programme of the Government' presupposes that this symposium should be solution orientated. It will therefore be helpful to draw lessons from our past history in order to learn from those experiences and to try to avoid mistakes of the past. To understand 'Church' and 'Government', we are in a way drawn to the issue of defi-nitions - a matter that has been so well presented in the previous paper (of Rev Mpanza), which to my mind describes an ideal situation.

\subsection{The Problem of Definitions and the Scope of the Church-Government Inter- vention}

The South African context does not allow us to talk freely of the 'Church' as if it were a homogeneous and harmonious entity. The controversial 'Kairos Document' tried to illustrate the complexities of the nature of the Church in South Africa by describing 'State Theology', 'Church Theology' and 'Prophetic Theology'. This bizarre nature of our South African church, as a matter of fact, was highlighted by the former State President, Mr F W de Klerk in 1990, when he remarked that the Church in South Africa could not talk with 'one voice'. This subsequently led to the Rustenburg Conference of the Church in South Africa, boycotted by the Nederduitsch Hervormde Kerk van Afrika which emphasises the gravity of this problem. 
At the same time, the Government was not acceptabie to all the peoples of this country as it deliberately chose to advance the interests of a select section of the population, especially those of Whites. This deliberate bias was aggravated when the Nationalist Party came into power in 1948. In its reign it introduced very oppressive laws, especially the Group Areas Act (1951), under which job reservation provisions were lodged, the Bantu Education Act (1953), and the Bantu Resettlement Act (1954), to name but four of the seven pillars ot Apartheid. These laws set scope of the operation of the government in terms of its politics, economy and social policies. The Church too was supposed to operate within the parameters of these laws. The important question we have to ask, though, is what was the Church's response to these laws. The Dutch Reformed Church, then perceived by many of its opponents as 'the government at prayer', said in a report:

The practice of the Church follows the doctrine of the State on the relation of the white and the black races to each other. The doctrine is, that the white race is and must remain the ruling race. The coloured and the black sections of the population occupy a strictly subordinate position. This is not due, as very generally supposed, to the accident of their colour: it is due to the lower stage of their cultural development ....

(Borchardt in Van Donk 1994:41)

The Nederduitsch Hervormde Kerk van Afrika's point of departure for many years was a policy of 'geen gelykstelling' (cf Joh Dreyer 1978:4), of which the bottom line was 'separate development'. The failure of the Nederduitsch Hervormde Kerk van Afrika, as pointed out by Ds M J J Redelinghuys (1978:39) in his article 'Is ons sonder skuld? (1)', was not to recognise that there were no equal rights and opportunities, no equal land distribution, no equal distribution of wealth and resources ... no equality at all. This led to very high proportions of poverty, deprivation and destitution among blacks. Therefore the Nederduitsch Hervormde Kerk van Afrika, as a church, also collaborated in the imbalances spearheaded by the government, which are greatly to blame for our present state of poverty.

Having said this, we can conclude that the Church-State intervention on humanitarian crises facing the country in the past was affected and determined by the scope outlined above. To put the case for co-operation between State and Church in resolving the poverty crisis in pẹspective, we will use 'the Problem of the Poor White' as an example. 


\subsection{The Problem of the 'Poor White'}

In 1923 a joint conference of civil organizations, church and government, attended by a high-profile delegation, was called to discuss 'the Problem of the Poor White' (Gesa 1923:1-2). In his opening speech the chairman, Ds P van Heerden, the Moderator of the Dutch Reformed Church (OVS), said that the success of that congress depended on three things:

* Ons moet sien,

* Ons moet voel, en

* Ons moet doen (Gesa 1923:3)

(And I hope it is with the same attitude today that we grapple with this similar matter.)

The issue (of the Poor White) was not a matter for the government alone. Both the Nederduitsch Hervormde Kerk van Afrika and the Dutch Reformed Church formed special church commissions to deal specifically with this matter. But the solution to the problem made headway in 1928 when the first 'Carnegie Commission of Investigation on the Poor White Question in South Africa' was instituted. It came up with a valuable five-part volume of findings and recommendations. One specific area of the report investigated the extent to which the Church was implicated in the social decline to poverty. The Commission said that, "in spite of the influence of the Church a section of the population has sunk into abject poverty. The question now arises whether the Church is to be held responsible to any degree for this state of affairs; if not deliberately, then through lack of zeal or through not applying the best remedies' (Carnegie 1932:47). A scrutiny of the church's state of being, policies, attitudes and methods indicated these to be both positive and negative. They could be summarised as follows, as pertaining to 'Co-operation between Church and State':

* The function of each: their labours converge intimately on the subject of care to the poverty-stricken (indigent) and the incapacitated, though for different reasons. The State's programme involves economic measures: provision of good housing and of employment; ensuring a respectable livelihood to the poor; improvement of environment and conditions of labour; the Church's programme involves social care and the moral and religious rehabilitation of the destitute. Then an observation was made by the commission that after relief the greatest task was to help the poor regain their lost character instilling a sense of self-reliance. 
* Factors in favour of co-operation: the Church has facilities; the State subsidises; the economical policy of the Church is thrifty in terms of expenditure; the experience (as inherent in preaching and deeds of charity), organisation (in terms of staff, infrastructure, accessibility to people, even in the most remote habitable parts of the country); control mechanisms at local, regional and national levels; and the idealism of the Church guaranteed success. We can therefore draw conclusions from this analysis for our intricate Church-State co-operation.

\subsection{An Evaluation of the Church - Government Relationship on issues of Poverty}

The co-operation between the Church and the government discussed above indicates that issues of poverty need the joint attention of both the Church and the State, for each has a particular contribution to make in the search for solutions. There are striking similarities, especially in the concern and moral obligation to act. But there are also moral differences which might have caused tension. The church's basis is divine obligation, but the government's basis is a political obligation especially aimed at pleasing the voters. The case of the National Party should refresh our memories. These divergent motives require of us as Church to carefully consider our entry points in government programmes which are based on specific political policies, which may not only be foreign to our Christian faith but also opposed to it. And therefore we need to understand the RDP carefully before we can finally arrive at the 'Co-operation between the Church and the Government on the RDP'.

\section{THE RECONSTRUCTION AND DEVELOPMENT PROGRAMME (AND THE GOVERNMENT)}

\subsection{Its background}

The RDP was originally an African National Congress policy document used in its campaign for the 1994 National Elections. In itself it is an exciting document, acclaimed to be widely consultative and well researched, and far-reaching in its promises of transforming the South African society. Its inclusiveness in addressing the needs of all the peoples of South Africa indicates that it derives its inspiration from the Freedom Charter of the African National Congress. And its holistic approach, touching on most political, social, educational and economic aspects of our lives as well as the fact that it comes in the wake of the 'Second Carnegie Inquiry into Poverty and Develop- 
ment in Southern Africa' of 1984, gives the impression that it has drawn its social analysis from this inquiry. The Reconstruction and Development Programme is now the hallmark of the Government of National Unity (GNU) upon which the success of this government hinges.

\subsection{Its motives}

Fundamental to the Reconstruction and Development Programme is the redressing of the imbalances existing because of the long history of deprivation and repression of the people of South Africa, of whom Blacks form the majority. Its goal is to see to it that (to put it in the words of Mr Nelson Mandela, on the occasion of his inauguration as the State President) 'never, never, never again shall it be that this beautiful land will again experience the oppression of one by another'. This is the bottom line that should cut throughout the society. It is a philosophy that rests on six basic principles of the Reconstruction and Development Programme, namely:

* An integrated and sustainable programme,

* A people-driven process,

* Peace and security for all,

* Nation-building

* Linking reconstruction and development,

* Democratisation of South Africa.

These principles should be co-ordinated in such a way that at the end of the day the poor are the beneficiaries of the provision of the following basic needs: jobs, land, housing, water, electricity, telecommunications, transport, a clean and healthy environment, nutrition, health care and social welfare.

\subsection{Its method (Praxis)}

The success of every system lies in its actual implementation. This is the challenge facing the Reconstruction and Development Programme. Therefore its method is:

* Involving organisations outside the government 'that are very different to the old apartheid order'; 2) Government structures at a national, regional and local level and 3) Financing by better organisation and rationalisation of existing systems; reformed taxation (ANC 1984:11). 


\subsection{Evaluation}

* The Reconstruction and Development Programme deliberately avoids reference to the church and talks very little if ever of religious bodies in its entirety. We may ask: does this silence presuppose a communist approach, and therefore undesirability for church involvement in the Reconstruction and Development Programme, or does it simply suggest the multi-religious or non-religious (a-religious) nature of the ANC-led government? What should then be the attitude of the Church in relation to the Reconstruction and Development Programme?

* The Reconstruction and Development Programme in its 1984-paper form is an ivory-tower fabrication that has not stood the test of time. The Reconstruction and Development Programme that confronts us today has lost to some extent the gloss and the glamour it had during its initial stage. It has been dented by the repulsiveness of 'the gravy train', the lack of experience, the corruption of some officials, the unavailability of funds, the distraction from basic issues confronting the poor, by petty squabbles, power struggles, resistance and lack of co-operation by other parties in the GNU, et cetera. This was admitted by Rev Stofile, the ANC chief whip, at a news conference on 21 September 1995. The realisation is that the government will still have to continue using the old instruments of the church and society to dispense of aid and charitable goods to the needy. Therefore this puts the Church back on centre stage as a means by which Reconstruction and Development Programme can achieve its goal. But who and what is the Church in this regard (cf 1st Carnegie Commission's description above)?

\section{THE CHURCH}

\subsection{The Church's Point of Entry to the Reconstruction and Development Programme}

The Church, despite policy changes here and there, remains, as far as its membership composition is concerned, the same Church it was in the apartheid era. The Nederduitsch Hervormde Kerk van Afrika and the Hervormde Kerk in Suidelike Afrika are still churches with vast differences as regards socio-political issues, both in theory, teaching and preaching on the one hand, and in physical outlook and experience, especially on the question of poverty (a point which Rev Mpanza has accurately described), on the other hand. I dare say that the Hervormde Kerk in Suidelike Afrika was deliberately tailor-made by the Nederduitsch Hervormde Kerk van Afrika, especially on the ability to understand issues of social responsibility. I do not need to enter into issues of 
the Nederduitsch Hervormde Kerk van Afrika's past policies of 'rassebeleid' and 'sendingbeleid'. Therefore, with these dire differences, it is not possible for us here to simply talk as 'the Church', but rather as churches. That being the case, our points of entry into the Reconstruction and Development Programme should necessarily differ. Otherwise, the Nederduitsch Hervormde Kerk van Afrika should make a deliberate and purposeful undertaking to correct the legacy of the past.

Until that is achieved, for now the Nederduitsch Hervormde Kerk van Afrika enters the Reconstruction and Development Programme from a point of advantage, with a theology, infrastructure, staff and experience well equipped to address issues of poverty. The Hervormde Kerk in Suidelike Afrika as an organic structure has none of the above. However, some individual congregations of the Hervormde Kerk in Suidelike Afrika, devoid of central control (worse still, in rejection of it) act intuitively to respond to local needs of their communities, in as far as opportunities become available. The Hervormde Kerk in Suidelike Afrika's point of entry is very difficult and problematic. The experience of the Hervormde Kerk in Suidelike Afrika is that the lack of an address (i.e. existing charity organisation) proved counter-productive in its attempt to win support from an overseas, diaconal organisation, COZA. This means that other churches (both Black and White - in the traditional sense) who have longestablished charity structures will continue to benefit. And this status quo may be perpetuated unless the situation is corrected.

\subsection{The Church's Point of Departure}

The Hervormde Kerk in Suidelike Afrika's point of departure with regard to the Reconstruction and Development Programme and poverty is, firstly, the Divine obligation (The diakonia, cf Rev Mpanza).

The second point is the injunction to 'do good unto all men, especially unto them who are of the house of faith' (Gl 6:10). These two points we share with the Nederduitsch Hervormde Kerk van Afrika. Secondly, it is the fact that deprivation and poverty are not only found among Blacks, but are felt deeply by the Hervormde Kerk in Suidelike Afrika as a Church and by its members as individuals. The Nederduitsch Hervormde Kerk van Afrika's second point of departure, I presume, should be based on a movement from exclusive white particularism to the Reconstruction and Development Programme's policy of inclusiveness, that is of accommodating people of other races, especially the Hervormde Kerk in Suidelike Afrika. We are however not so naive as to think that the whole concept of the Reconstruction and Development Programme is acceptable to all people, especially whites. Its intent to redistribute wealth and land may be met with opposition, even among the Nederduitsch Hervormde Kerk van Afrika members. 


\subsection{The Church's Cutting Edge}

If the Reconstruction and Development Programme is to achieve its divine goal in the hands of the Church, it requires through the instrumentality of the Word of God, the vigilance of the Church which was assigned to the deacons, namely to prevent those who are not the rightful beneficiaries of relief and aid from enriching themselves at the expense of the needy, and to see to it that those who dispense of these aids do not fraudulently squander them to satisfy their greed. The Church should also guard against a dependence syndrome (cf Rev Mpanza).

It should assist local communities to make right and informed decisions. At a Community Development Trust workshop, 1993, in Randburg, a social worker reported that one community which lacked clean water supply insisted on having a church bell to be bought with the aid funds. The community leaders argued that they needed the bell so that they could call people together in the events of death, disaster and other issues of the community. It was not until the bell was erected that they gave in to the idea of the installation of a water supply system and other health needs of the community. While this could be portrayed as democracy, to my mind it is but an uninformed and dangerous democracy, and Reconstruction and Development Programme can be harmed by such decisions.

\section{CONCLUSION}

While Reconstruction and Development Programme is a sweet sound of hope to many, it would seem that it will be executed by the already advantaged church and social organisations who have experience, infrastructure, adequate and able staff to respond timeously and efficiently to what the Reconstruction and Development Programme offers, who may already be operating among better-off communities.

In the light of the above the Hervormde Kerk in Suidelike Afrika should argue that it is the ecclesiastical responsibility of the Nederduitsch Hervormde Kerk van Afrika to the Hervormde Kerk in Suidelike Afrika as its mission church, sister church and fellow church (koinonia) to assist it, as a matter of urgency, to enable it to be on the same par with other churches to benefit in order for it to be able to serve its members and the surrounding communities the fruits of the Reconstruction and Development Programme.

\section{Works consulted}

ANC 1994. The Reconstruction and Development Programme: A Policy Framework. Johannesburg: Umanyano Publication.

Dreyer, Joh 1978. Gelykstelling, in Van Wyk, D J C (red). Stemme uit die Verlede, 4-

7. Pretoria: HAUM. 
Gesamentlike Kongres oor die arme blanke vraagstuk in die Raadsaal te Bloemfontein, 4 en 5 Julie 1923. Bloemfontein: Nasionale Pers.

Redelinghuys, M J J 1978. 'Is ons sonder skuld? (1)', in Van Wyk, D J C (red). Stemme uit die Verlede, 37-41. Pretoria: HAUM.

Report of the Carnegie Commission 1932. The Poor White Problem in South Africa, Part V: Sociological Report. Stellenbosch: Pro Ecclesia Drukkery.

Nash, M 1984. Conference Paper 242, in Second Carnegie Inquiry to Poverty and Development in Southern Africa.

Van Donk, M 1994. Land and the Church - The Case of the Dutch Reformed Churches, in Relevant Church Series. A Western Province Council of Churches Puvlication, 1 (April). 